\title{
LOGICAL FUNCTION DALAM TEORI SYSTEMIC FUNCTIONAL GRAMMAR (SFG)
}

Ruly Adha

IAIN Langsa

adharuly@yahoo.com

\begin{abstract}
Abstraksi
Systemic Functional Grammar merupakan teori yang diperkenalkan oleh M.A.K. Halliday, ahli linguistik Australia. Teori ini masih tergolong belum begitu lama dipakai walaupun Halliday sudah mempublikasikannya sekitar tahun 80an. SFG merupakan teori tata bahasa yang lebih menekankan pada fungsi atau peran bahasa itu sendiri. Di dalam teori SFG, manusia menggunakan bahasa dengan tujuan untuk memenuhi tiga fungsi dalam kehidupannya yang dikenal dengan metafunctions, yaitu fungsi untuk merepresentasikan pengalaman yang disebut ideational function, fungsi untuk menukarkan pengalaman yang disebut interpersonal function, dan fungsi untuk mengorganisasikan pengalaman yang disebut textual function. Ideational function dibagi lagi menjadi dua, yaitu experiential function dan logical function. Tulisan ini hanya membahas tentang logical function dalam teori SFG. Logical Function merupakan fungsi yang berkaitan dengan hubungan logis antara satu klausa dengan klausa lainnya yang meliputi dua aspek, yaitu interdependency relations dan logico-semantic relations. Kedua aspek tersebut akan dijelaskan secara detail dalam tulisan ini.
\end{abstract}

Kata Kunci

Systemic Functional Grammar, Metafunctions, Logical Function

\section{PENDAHULUAN}

Systemic Functional Grammar, atau juga dikenal dengan Systemic Functional Linguistics, merupakan sebuah teori yang pertama kali diperkenalkan oleh Michael Alexander Kirkwood Halliday, seorang ahli linguistik Australia kelahiran Inggris. Awalnya, Halliday mempublikasikan teori ini pada tahun 1985 dalam judul Systemics Background. Namun, pada saat itu belum mendapat 
perhatian serius dari para ahli bahasa lain. Akhirnya, pada tahun 1994, Halliday mempublikasikan bukunya yang berjudul An Introduction to Functional Grammar yang sekarang menjadi referensi utama dari teori Systemic Functional Grammar yang banyak digunakan oleh para ahli bahasa fungsional di dunia. Systemic Functional Grammar adalah sebuah metode tata bahasa yang merupakan bagian dari pendekatan semiotik sosial terhadap bahasa yang disebut systemic linguistics. Istilah systemic mengacu kepada suatu pandangan bahwa bahasa itu merupakan sebuah sistem jaringan yang saling berhubungan dalam menciptakan makna, sedangkan istilah functional mengindikasikan bahwa pendekatannya adalah metafunction (Suhadi, 2012).

Functional mengacu kepada suatu pendekatan terhadap bahasa yang lebih menekankan pada peran atau fungsi bahasa tersebut. Dengan kata lain, fungsi yang diberikan manusia kepada bahasa di dalam kehidupan mereka sebagai makhluk sosial. Istilah functional memiliki tiga makna yang saling berkaitan, yaitu functional in terms of buman needs, functional with reference to use of language, dan functional in terms of linguistic constituent relations (Saragih, 2006).

Functional in terms of buman needs berdasar pada prinsip bahwa bahasa disusun atas tanggapan terhadap kebutuhan manusia sebagai makhluk sosial. Dengan kata lain, struktur bahasa ditentukan oleh kebutuhan masyarakat dimana bahasa itu digunakan. Sebagai contoh, jika seekor harimau dapat dijumpai dalam sebuah masyarakat dan kelompok masyarakat tersebut perlu untuk mengidentifikasikan dan menjelaskan hewan tersebut, maka di dalam bahasa kelompok masyarakat tersebut akan memiliki kata 'harimau'. Sama halnya, di dalam masyarakat Indonesia, kebutuhan masyarakat untuk mengidentifikasikan berbagai jenis makanan yang terbuat dari nasi menyebabkan banyaknya kata-kata leksikal yang berhubungan dengan nasi. 
Functional with reference to use of language merupakan sebuah konsep dimana manusia menggunakan bahasa dengan tujuan untuk memenuhi tiga fungsi dalam kehidupannya yang dikenal dengan metafunctions, yaitu fungsi untuk merepresentasikan pengalaman yang disebut ideational function, fungsi untuk menukarkan pengalaman yang disebut interpersonal function, dan fungsi untuk mengorganisasikan pengalaman yang disebut textual function. Ideational function dibagi lagi menjadi dua, yaitu experiential function dan logical function.

Functional in terms of linguistic constituent relations mengimplikasikan bahwa setiap elemen unit bahasa seperti klausa, frase, kata, morfem memiliki fungsi. Dengan kata lain, sebuah unit berfungsi di dalam sebuah unit yang lebih besar diatasnya dan akhirnya fungsi dari setiap unit tersebut ditentukan oleh fungsi penggunaan bahasa (Saragih, 2006).

Semua jenis tata bahasa dapat dikelompokkan menjadi dua kategori, yaitu logical-philosophical atau dikenal dengan formal grammar dan ethnographic-descriptive atau dikenal dengan functional grammar. Systemic Functional Grammar masuk ke dalam kelompok ethnographic-descriptive. Perbedaan utama dari kedua kelompok tata bahasa tersebut dapat dilihat pada tabel di bawah ini (Saragih, 2006,p.2-3).

\begin{tabular}{|c|l|l|l|}
\hline No & \multicolumn{1}{|c|}{ Aspek } & $\begin{array}{c}\text { Logical-Philosophical } \\
\text { (Formal Grammar) }\end{array}$ & \multicolumn{1}{|c|}{$\begin{array}{c}\text { Ethnographic- } \\
\text { Descriptive } \\
\text { (Functional } \\
\text { Grammar) }\end{array}$} \\
\hline 1 & Orientasi & Bentuk - Makna Formal & $\begin{array}{l}\text { Makna - Bentuk } \\
\text { Fungsional }\end{array}$ \\
\hline 2 & Anggapan & Bahasa sebagai bentuk & Bahasa sebagai sumber \\
\hline 3 & Bahasa berkaitan & Pikiran, neurologi, dan & Fenomena sosial, \\
\hline
\end{tabular}




\begin{tabular}{|c|l|l|l|}
\hline & erat dengan & psikologi & $\begin{array}{l}\text { sosiologi, dan konteks } \\
\text { sosial }\end{array}$ \\
\hline 4 & $\begin{array}{l}\text { Tata bahasa } \\
\text { dianggap } \\
\text { berhubungan } \\
\text { dengan }\end{array}$ & Akal, kalimat & Anthropology, teks \\
\hline 5 & Metode Analisis & $\begin{array}{l}\text { Ilmiah, tidak ada } \\
\text { konteks sosial, data yang } \\
\text { ideal }\end{array}$ & $\begin{array}{l}\text { Semiotik, konteks sosial, } \\
\text { data bahasa yang alami }\end{array}$ \\
\hline 6 & $\begin{array}{l}\text { Pendukung } \\
\text { Modistae, Bloomfield, } \\
\text { Chomsky, Pike }\end{array}$ & $\begin{array}{l}\text { Hjelmslev, Matesius, } \\
\text { Firth, Halliday, Martin }\end{array}$ \\
\hline 7 & $\begin{array}{l}\text { Kebanyakan } \\
\text { dikembangkan di }\end{array}$ & $\begin{array}{l}\text { Amerika Serikat } \\
\text { Eropa }\end{array}$ \\
\hline
\end{tabular}

Suhadi (2012) juga mengatakan bahwa bahasa digunakan dalam tiga fungsi yang berbeda yang disebut dengan metafungsi bahasa. Metafungsi bahasa dapat dibagi menjadi tiga jenis, yaitu:

1. Ideational function yaitu fungsi dimana bahasa digunakan untuk memahami dan mengekspresikan persepsi pembicara terhadap dunianya dan terhadap kesadarannya. Fungsi ini dibagi lagi menjadi dua bagian, yaitu:

a. Experiential Function yaitu fungsi dimana klausa (kalimat) merupakan representasi dari pengalaman dalam bentuk transitivity structure yang direpresentasikan oleh process dan dihubungkan dengan participant dan circumstance.

b. Logical Function berkaitan dengan hubungan diantara ide-ide dalam klausa-klausa kompleks (majemuk). 
2. Interpersonal Function yaitu fungsi dimana bahasa digunakan untuk memungkinkan pembicara berpartisipasi atau ikut berperan dalam komunikasi dengan orang lain. Fungsi ini melibatkan mood structure dan modality. Mood structure menunjukkan perubahan verbal dalam komunikasi. Modality merupakan opini atau penilaian pembicara terhadap fungsi ujaran dalam klausa. Modality meliputi modalization dan modulation. Modalization meliputi probability dan usuality, sedangkan modulation meliputi obligation dan inclination.

3. Textual Function yaitu fungsi dimana bahasa digunakan untuk menghubungkan apa yang dikatakan (ditulis) dengan dunia nyata dan peristiwa-peristiwa linguistik lainnya. Fungsi ini melibatkan penggunaan bahasa dalam mengorganisasikan teks dalam bentuk thematic structure yang terdiri dari theme dan rheme.

Tulisan ini hanya membahas tentang logical function yang merupakan bagian dari ideational function, fungsi dimana bahasa digunakan untuk memahami dan mengekspresikan persepsi pembicara terhadap dunianya dan terhadap kesadarannya. Dalam logical function ada dua aspek yang akan dibahas, yaitu interdependency relations dan logico-semantic relations.

\section{PEMBAHASAN}

Kalimat (klausa) yang dihasilkan manusia dapat berbentuk simple sentence yaitu kalimat yang hanya terdiri dari satu kata kerja saja. Namun, kalimat juga dapat berbentuk gabungan antara beberapa simple sentence yang disebut dengan kalimat majemuk. Kalimat majemuk ini terdiri dari kalimat majemuk setara atau compound sentence dan kalimat majemuk bertingkat atau complex sentence. Akan tetapi, dalam Systemic Functional Grammar kalimat majemuk tersebut dikenal dengan istilah Clause Complex baik bentuk yang 
setara ataupun bentuk yang bertingkat. Hubungan clause complex dalam logical function meliputi interdependency relation dan logico-semantic relation.

\section{Interdependency Relation}

Interdependency relation disebut juga dengan istilah taxis. Taxis merupakan hubungan diantara klausa-klausa yang membentuk clause complex. Hubungan taxis tersebut dapat berbentuk hubungan bebas (independent) dan hubungan terikat (dependent). Taxis yang berbentuk bebas disebut dengan istilah parataxis, sedangkan taxis yang berbentuk terikat disebut dengan istilah hypotaxis.

\section{a. Parataxis}

Parataxis merupakan klausa kompleks yang masing-masing klausanya memiliki status bebas atau tidak terikat dengan klausa lain. Parataxis ini dulu dikenal dengan istilah kalimat majemuk setara atau compound sentence. Di dalam parataxis, kalusa-klausa bebas tersebut biasanya digabungkan dengan menggunakan kata penghubung koordinatif (coordinative conjunction), seperti and, but, or, then, either...or, neither...nor, not only...but also, so, dan lain sebagainya. Kata penghubung conjunctive adjuncts juga dapat digunakan di parataxis, seperti however, anyway, in the mean time, dan lain sebagainya. Klausa parataxis dianalisis dengan menggunakan angka 1, 2, 3, dan seterusnya, sebagai contoh:

1. Putri adalah anak yang terpandai dan dia juga merupakan bintang 1 2 kelas di sekolahnya

2. Sinta sudah berusaha semaksimal mungkin di kompetisi itu tapi 1 akhirnya dia harus menerima kekalahan dalam kompetisi itu. 2

3. We planned to buy a new house, so we started to save our money. 1 2 
4. I need to go to the store, $\underline{\text { but I'm so tired, }}$ so I ask my brother to help 123 me.

5. The room is very dark; however, I can find my keys.

12

\section{b. Hypotaxis}

Hypotaxis merupakan klausa kompleks yang salah satu klausanya memiliki status bebas dan kalusa lainnya berstatus terikat. Hypotaxis dulu dikenal dengan istilah kalimat majemuk bertingkat atau complex sentence. Klausa bypotaxis menggunakan kata penghubung subordinatif (subordinative conjunction), seperti because, although, so that, dan lain sebagainya. Klusa bypotaxis dianalisis dengan menggunakan abjad Yunani $\alpha, \beta, \gamma$, dan seterusnya. Klausa yang berstatus bebas ditandai dengan $\alpha$, sebagai contoh:

1. Saya sudah mempersiapkan semua bekal sebelum kalian datang. $\alpha \quad \beta$

2. Kita akan segera melakukan operasi apabila sudah ada izin dari $\alpha$ $\beta$ atasan.

3. He did not come to the class yesterday because he was sick. $\alpha$ $\beta$

4. Robert came to the meeting although it was raining heavily. $\alpha$

5. If she got scholarship, she would go abroad although her parents $\alpha$ did not support her. $\beta$ $\gamma$

\section{Logico-Semantic Relation}

Logico-semantic relation berkaitan dengan hubungan makna diantara klausa di dalam klausa kompleks. Logico-semantic relation terdiri dari dua bagian, yaitu:

JL3T. Vol. IV, No. 1 July 2018 
1. Expansion merupakan hubungan antara klausa dimana klausa utamanya diperluas oleh klausa lainnya. Expansion dibagi lagi menjadi tiga jenis, yaitu:
a. Elaboration (marked by $=$ )
b. Extension (marked by + )
c. Enhancement (marked by x)

2. Projection merupakan hubungan antara klausa dimana klausa utamanya memproyeksikan klausa lainnya. Projection dibagi lagi menjadi dua jenis, yaitu:
a. Locution (marked by ")
b. Idea (marked by )

\section{A. Expansion}

\section{Elaboration}

Elaboration merupakan jenis perluasan makna klausa pertama oleh klausa lainnya (Halliday, 1994). Dalam analisis logical function, elaboration ditandai dengan simbol sama dengan $(=)$. Elaboration dapat dijumpai pada parataxis ataupun bypotaxis.

\section{a. Paratactic Elaboration $(1=2)$}

Paratactic elaboration dibagi menjadi exposition, exemplification, dan clarification. Exposition merupakan hubungan antara dua klausa bebas di dalam sebuah klausa kompleks dimana klausa bebas yang satu menegaskan kembali klausa bebas yang lain. Kata penghubung yang biasa digunakan adalah in other words, that is to say, atau bisa juga tanpa menggunakan kata penghubung, hanya dengan memakai tanda dash ( - ) (Suhadi, 2012). Sebagai contoh:

1. The man cannot see anything; in other words, he is blind. 
2. The students who win the competition are from this school, that is to 1 say, the school is the best one in this city. $=2$

3. After finishing his study at university, he works as a leader in his 1 father's company - he becomes a manager now. $=2$

Sementara itu, exemplification merupakan hubungan antara dua klausa bebas di dalam sebuah klausa kompleks dimana salah satu klausa bebas menjelaskan secara khusus klausa bebas lainnya dengan memberikan sebuah contoh. Kata penghubung yang biasa digunakan adalah for example, for instance, dan lain sebagainya, atau bisa juga dengan memakai tanda dash. Sebagai contoh:

1. This school has some strict rules; for instance, the students cannot 1 $=2$ wear any jewelleries, bring motorcycle, and bring cellular phone.

2. You can choose any kind of faculty in this university; for example, 1 you can choose faculty of English literature, economy, law, and $=2$ agriculture.

3. My sister was appointed as the student of the year $-\underline{\text { she was always }}$ 1 $=2$ present in the class.

Jenis yang terakhir yaitu clarification. Clarification merupakan hubungan antara dua klausa bebas di dalam sebuah klausa kompleks dimana salah satu klausa bebas mengklarifikasi klausa bebas lainnya dengan memberikan penjelasan. Kata penghubung yang biasa digunakan adalah in fact, actually, indeed, for, dan lain sebagainya atau bisa juga dengan memakai tanda dash. 
1. He was not surprised - it was what he had expected.

$$
1=2
$$

(Suhadi, 2012,p.118)

2. The machine is not working, for he forgets to fill it with gasoline.

$$
1=2
$$

3. The student cannot answer all the questions; actually, he did not

$$
1
$$
study last night.

\section{b. Hypotactic Elaboration $(\alpha=\beta)$}

Hypotactic elaboration merupakan hubungan antara klausa bebas dan klausa terikat di dalam sebuah klausa kompleks dimana klausa terikat memperluas makna klausa bebas dengan menggunakan non-restrictive relative clause. Sebagai elaborator, klausa terikat dapat berbentuk klausa finite dan nonfinite.

Finite bypotactic elaboration ditandai dengan menggunakan kata penghubung seperti who, whom, whose, when, where, why, which, how dengan syarat harus didahului tanda koma untuk menunjukkan bahwa klausa tersebut nonrestrictive. Sebagai contoh:

1. The police found the place, where he murdered his girlfriend. $\alpha$ $=\beta$

2. I meet Mr. Smith, whom you admire very much.

$$
\alpha \quad=\beta
$$

3. I never forget the date, when I met you.

$$
\alpha \quad=\beta
$$

Sementara itu, non-finite hypotactic elaboration merupakan hubungan antara klausa bebas dan klausa terikat di dalam sebuah klausa kompleks dimana klausa terikat yang berbentuk klausa non-finite memperluas makna klausa bebas. Non-finite bypotactic elaboration ditandai dengan penggunaan infinitive, present participle, past participle, gerund, nominal group, prepositional phrase 
yang biasanya didahului tanda koma untuk menunjukkan bahwa klausa tersebut merupakan keterangan tambahan terhadap unsur sebelumnya. Sebagai contoh:

1. My ambition, to be an artist, seems to be impossible.

$$
\alpha \quad=\beta \quad \alpha
$$

2. My brother has a hobby, collecting stamps.

$$
\alpha \quad=\beta
$$

3. The child always uses his blue hat, given by his father.

$$
\alpha
$$

$$
=\beta
$$

\section{Extension}

Extension merupakan jenis expansion yang berkaitan dengan hubungan dua klausa di dalam sebuah klausa kompleks dimana salah satu klausa menambahkan makna klausa yang lain. Extension ditandai dengan simbol tambah $(+)$. Extension dapat dijumpai pada parataxis dan hypotaxis.

\section{a. Paratactic Extension $(1+2)$}

Paratactic extension dibagi menjadi addition, variation, dan alternation. Paratactic extension jenis addition merupakan hubungan antara dua klausa bebas dimana salah satu klausa berisi informasi tambahan dari klausa yang lain. Kata penghubung yang biasa digunakan adalah furthermore, in addition, besides, moreover, on the other hand, in fact, as a matter of fact dan lain sebagainya. Sebagai contoh:

1. Robert is the cleverest student in the class, and besides he has many

$$
1+2
$$

talents.

2. He seems to be a good man, but in fact he has done many crimes.

$$
1+2
$$

3. She is the most beautiful girl in her family, and also she is the

$$
1
$$$$
+2
$$
cleverest. 
Selanjutnya, paratactic extension jenis variation merupakan hubungan antara dua klausa bebas dimana salah satu klausa menggantikan makna klausa yang lain. Kata penghubung yang biasa digunakan adalah instead, only, yet, dan lain sebagainya. Sebagai contoh:

1. ذim and Susan have married for ten years, and yet they have no

1 $+2$ children.

2. Ruby is the cleverest student, but only she never did her homework. $1+2$

3. He never brings his family to any restaurants, but instead he always 1 $+2$ goes to some expensive restaurants with his friends.

Jenis terakhir dari paratactic extension adalah alternation. Alternation merupakan hubungan antara dua klausa bebas dimana salah satu klausa berisi pilihan atas klausa yang lain. Kata penghubung yang biasa digunakan adalah or else, either...or, neither...or, alternatively, dan lain sebagainya. Sebagai contoh:

1. You can find the references in the library, alternatively you can search 1 $+2$ in google.

2. You must go to the station now, or else you will miss the bus.

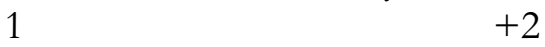

3. Either you answer this simple question, or you will be given another $1+2$ difficult question.

\section{b. Hypotactic Extension $(\alpha+\beta)$}

Hypotactic extension merupakan hubungan antara klausa bebas dan klausa terikat di dalam sebuah klausa kompleks dimana klausa terikat menambahkan makna dari klausa bebas. Klausa terikat tersebut dapat berbentuk klausa finite dan klausa non-finite. Di dalam klausa finite bypotactic 
extension, kata penghubung yang biasa digunakan adalah whereas, while, except that, unless, dan lain sebagainya. Sebagai contoh:

1. You will never pass the examination, unless you study hard.

$$
\alpha+\beta
$$

2. The girl is watching TV, while her mother is cooking for her lunch.

$$
\alpha+\beta
$$

3. I can lend you one of my notebooks tomorrow, except that one of $\alpha$ $+\beta$ them is infected by some virus. (Suhadi, 2012,p.122)

Sementara itu, klausa non-finite bypotactic extension ditandai dengan penggunaan infinitive, present participle, past participle, gerund, nominal group, atau dengan menggunakan kata penghubung besides, instead of, without, other than, dan lain sebagainya. Sebagai contoh:

1. You can answer all questions in the test, without studying hard.

$$
\alpha+\beta
$$

2. My father always reads newspaper every morning, finding some new information.<smiles>[131I-]</smiles>

3. You can recycle those old papers, instead of burning them.

$\alpha$ $+\beta$

\section{Enhancement}

Enhancement merupakan jenis expansion yang berkaitan dengan hubungan dua klausa di dalam sebuah klausa kompleks dimana salah satu klausa menambahkan makna klausa yang lain. Enhancement ditandai dengan simbol kali ( $\mathrm{x}$ ). Extension dapat dijumpai pada parataxis dan hypotaxis.

\section{a. Paratactic Enhancement (1 x 2)}

Paratactic enhancement dapat menunjukkan beberapa ciri sirkumstansial, seperti: time, place, manner, condition, purpose, cause, concession, dan lain sebagainya. Kata penghubung yang biasa digunakan adalah so, then, for, but, yet, still, and 
then, and so, and yet, and therefore, at that time, at the very moment, soon afterwards, until then, in that case, dan lain sebagainya. Sebagai contoh:

1. You have failed in the last exam, and so you have to follow 1 $\mathrm{x} 2$ the next exam. (cause-effect)

2. He had been punished for his failure in the test; $\underline{\text { still, he was lazy }}$ $1 \quad \mathrm{x} 2$ to study hard. (concession)

3. The students have finished doing their homework, and then they are 1 $\mathrm{x} 2$ now waiting for the score. (temporal)

\section{b. Hypotactic Enhancement $(\alpha \times \beta)$}

Hypotactic enhancement merupakan hubungan antara klausa bebas dan klausa terikat di dalam sebuah klausa kompleks dimana klausa terikat menambahkan makna dari klausa bebas. Klausa terikat tersebut dapat berbentuk klausa finite dan klausa non-finite. Di dalam klausa finite bypotactic enhancement, ada beberapa karakteristik sirkumstansial yang dapat ditemukan, seperti: temporal, spatial, manner, comparison, condition, purpose, cause, result, concession, dan lain sebagainya. Sebagai contoh:

- Temporal

a. After I finished my study, I decided to go abroad.

$$
\mathrm{x} \beta \quad \alpha
$$

b. You must check the oil before you start the engine.

$\alpha$

$\mathrm{x} \beta$

- Spatial

a. You may sit wherever you want.

$\alpha \quad \mathrm{x} \beta$

b. Whither you go, I will follow you.

$\mathrm{x} \beta \quad \alpha$

JL3T. Vol. IV, No. 1 July 2018 
- Manner
a. Do the exercise as I instruct you to do.
$\alpha \quad x \beta$
b. The man walked as if he were drunk.

$$
\alpha \quad \mathrm{x} \beta
$$

- Comparison
a. Liza is as clever as Suzan (is).
$\alpha \quad x \beta$
b. Jack loves you more $\frac{\text { than (he loves) Mary. }}{\alpha \beta}$.

- Reason
a. The student was punished by his teacher because he did not do $\alpha \quad x \beta$ his homework.

b. Since there were no students in the class, the teacher cancelled $x \beta$ $\alpha$ the examination.

- Purpose
a. Jack pretended to be a good student for the purpose that he could get high scores from the teacher.
b. He went to the station early so that he could meet his girlfriend $\alpha$ $\mathrm{x} \beta$ for the last time.

- Result
a. The test are so difficult that nobody can pass it. $\alpha \quad x \beta$
b. He was so annoying that all his friends do not like him. $\alpha$ $\mathrm{x} \beta$ 
- Condition

a. If I am invited, I will come to her party.

$\mathrm{x} \beta \quad \alpha$

b. You will get bad scores in the exam unless you study hard.

$\alpha \quad \mathrm{x} \beta$

- Concession

a. Although he failed in the exam, he did not feel sad.

$x \beta \quad \alpha$

b. He goes to campus by bus everyday while his father is one of the $\alpha$ richest man in the town. (Suhadi, 2012,p.129)

$\mathrm{x} \beta$

Sementara itu, klausa non-finite bypotactic enhancement dibedakan menjadi tiga jenis, yaitu with conjunction and non-finite clause, with non-finite clause, dan with prepositional phrase. Sebagai contoh:

- With conjunction and non-finite clause

a. Every student should do the test as instructed.

$$
\alpha \quad x \beta
$$

b. Though having good scores, she was not proud.

$$
\mathrm{x} \beta \quad \alpha
$$

- With non-finite clause

a. He bought a new DVD player to play movies and music.

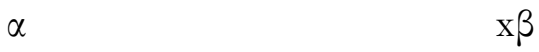

b. To avoid your house from robbery, you have to put CCTV

$\mathrm{x} \beta \quad \alpha$

in every room.

- With prepositional phrase

a. Before he worked in this bank, he was a manager in his father's $\mathrm{x} \beta$

$\alpha$

company.

b. You will never be allowed to drive a car without having a driving

$\alpha$

$\mathrm{x} \beta$ 
license.

\section{B. Projection}

\section{Locution}

Locution merupakan salah satu jenis projection yang berkaitan dengan hubungan dua klausa di dalam sebuah klausa kompleks dimana salah satu klausa memproyeksikan makna klausa yang lain. Dalam analisis logical function, locution ditandai dengan simbol ( “). Locution menggunakan proses verbal seperti say, tell, ask, answer, reply, insist, complain, cry, shout, dan lain sebagainya. Locution dapat dijumpai pada parataxis ataupun hypotaxis.

\section{a. Paratactic Locution (1 “ 2)}

Paratactic locution dahulu lebih dikenal dengan istilah kalimat langsung atau direct speech. Klausa-klausa di dalam paratactic locution bersifat bebas, jadi polanya dapat dibalik atau bertukar. Sebagai contoh:

1. She told me, "Jack will come to my house tomorrow." "2

2. "Jack will come to my house tomorrow", she told me. "2

1

3. The teacher commanded us, "Do the exercise on page 11." 1

4. "Do the exercise on page 11", the teacher commanded us. "2 1

\section{b. Hypotactic Locution ( $\alpha$ “ $\beta$ )}

Hypotactic locution dahulu lebih dikenal dengan istilah kalimat tidak langsung atau indirect speech. Klausa bypotactic locution dapat berbentuk finite dan non-finite.

- Finite Hypotactic Locution

a. She told me that Jack would come to my house the next day. $\alpha$ " $\beta$

b. The man asked his employee who could open that box. " $\beta$ 
- Non-Finite Hypotactic Locution

a. The teacher commanded us to do the exercise on page 11.

$\alpha$ " $\beta$

b. The teacher reminded us not to make noise in the class.

$\alpha$

" $\beta$

\section{Idea}

Idea merupakan salah satu jenis projection yang berkaitan dengan hubungan dua klausa di dalam sebuah klausa kompleks dimana salah satu klausa memproyeksikan makna klausa yang lain. Dalam analisis logical function, idea ditandai dengan simbol ( "). Idea menggunakan proses mental seperti think, imagine, plan, consider, intend, desire, mean, regard, wish, want, dan lain sebagainya. Idea dapat dijumpai pada parataxis dan hypotaxis.

\section{a. Paratactic Idea (1 ‘ 2$)$}

Paratactic idea merupakan hubungan antara dua klausa bebas di dalam sebuah klausa kompleks dimana salah satu klausa memproyeksikan klausa yang lain dengan menggunakan proses mental dalam bentuk kalimat langsung atau direct speech. Kalusa paratactic idea juga bisa dibalik atau bertukar. Sebagai contoh:

1. He thought, "I will tell his secret."

1 '2

2. "I will tell his secret", he thought.

'2 1

3. I imagined, "He will raise my salary."

12

4. "He will raise my salary", $\underline{\text { I imagined. }}$

'2 1

\section{b. Hypotactic Idea $\left(\alpha^{\prime} \beta\right)$}

Hypotactic idea merupakan hubungan antara klausa terikat dan klausa bebas di dalam sebuah klausa kompleks dimana klausa bebas 
memproyeksikan klausa terikatnya dengan menggunakan proses mental dalam bentuk kalimat tidak langsung atau indirect speech. Klausa bypotactic idea dapat berbentuk finite dan non-finite. sebagai contoh:

- Finite Hypotactic Idea

a. He thought that I would tell his secret.

$\alpha$ ' $\beta$

b. I imagined that he would raise my salary. $\alpha$ ' $\beta$

- Non-Finite Hypotactic Idea

a. The teacher wanted all the students to follow TOEFL prediction $\alpha$ ' $\beta$

test.

b. My friend thought to commit suicide.

$\alpha$ ' $\beta$

\section{KESIMPULAN}

Systemic Functional Grammar merupakan teori yang diperkenalkan oleh M.A.K. Halliday, ahli linguistik Australia. Di dalam teori SFG, manusia menggunakan bahasa dengan tujuan untuk memenuhi tiga fungsi dalam kehidupannya yang dikenal dengan metafunctions. Salah satu fungsi dalam metafunctions tersebut ialah logical function. Logical Function merupakan fungsi yang berkaitan dengan hubungan logis antara satu klausa dengan klausa lainnya yang meliputi dua aspek, yaitu interdependency relations dan logico-semantic relations. Logical Function berkaitan dengan hubungan diantara ide-ide dalam klausa-klausa kompleks (majemuk). Interdependency relation disebut juga dengan istilah taxis yang terdiri dari parataxis atau kalimat majemuk setara dan hypotaxis atau kalimat majemuk bertingkat. Sementara itu, logico-semantic relation berkaitan dengan hubungan makna diantara klausa dalam klausa kompleks. Logico-semantic relation terdiri dari dua bagian, yaitu: 
1. Expansion merupakan hubungan antara klausa dimana klausa utamanya diperluas oleh klausa lainnya, yang terdiri dari:
a. Elaboration $(=)$
b. Extension $(+)$
c. Enbancement $(\mathrm{x})$

2. Projection merupakan hubungan antara klausa dimana klausa utamanya memproyeksikan klausa lainnya, yang terdiri dari:
a. Locution (")
b. Idea (")

\section{REFERENSI}

Bloor, T. \& Bloor, M. (1995). The functional analysis of English: A Hallidayan approach. New York: Arnold.

Eggins, S. (2004). An introduction to systemic functional linguistics. London: Continuum International Publishing Group.

Gerot, L. \& Wignel, P. (1994). Making sense of functional grammar. Sydney: Gerd Stabler.

Halliday, M.A.K. (1994). An introduction to functional grammar. London: Edward Arnold.

Saragih, A. (2006). Introducing systemic functional grammar. Medan: English Department, Faculty of Languages and Arts, The State University of Medan.

Siewierska, A. (1991). Functional grammar. New York: Routledge.

Suhadi, J. (2012). Introduction to English functional grammar. Medan: Faculty of Literature UISU Medan.

Thompson, G. (1996). An Introduction to functional grammar. Tokyo: Arnold Ltd. 